\title{
Financial Performance Dan Market Share Pada Bank Umum Syariah Devisa Indonesia: Perspektif Teori Stakeholder
}

\author{
Nikmatul Fuadah dan Fifi Hakimi \\ Universitas Airlangga \\ Email: Nikmatul.fuadah-2018@pasca.unair.ac.id, \\ Diterima: Juni 2020 ; Dipublikasikan Juli 2020
}

\begin{abstract}
Penelitian ini menggunakan analisis analisis teori stakeholder yang belum diterapkan dalam beberapa penelitian sebelumnya. Penelitian ini juga penting, karena bank perlu mendapatkan informasi tentang determinasi dampak pada market share, selama market share dijadikan sebagai kunci pertumbuhan perusahaan dan cerminan untuk para stakeholder dalam menilai financial performancenya. Berdasarkan latar belakang yang telah dibahas sebelumnya, peneliti melakukan penelitian ini bertujuan untuk memahami bagaimana financial performance mempengaruhi marketshare Bank Syariah Indonesia. Metode penelitian ini menggunakan regresi data panel, dengan model yang digunakan pada penelitian ini adalah fixed effect dengan menggunakan aplikasi Eviews 10. Hasil dari penelitian ini menunjukkan bahwa secara simultan seluruh variabel eksogen (ROA, NPF, BOPO dan FDR) berpengaruh signifikan terhadap variabel endogen (market share). Dilihat pada $\mathrm{R}^{2}$ ditujukan bahwa variasi model endogen pada model market share dapat dijelaskan oleh variabel- variabel eksogen ROA, NPF, BOPO, dan FDR sebesar $62 \%$ dan 38\% dipengaruhi oleh variabel lainnya diluar variabel eksogen yang digunakan penelitian ini. Hasil secara parsial variabel ROA, NPF, BOPO, dan FDR berpengaruh negatif signifikan terhadap market share.
\end{abstract}

Kata Kunci: ROA,NPF,BOPO,FDR,market share.

\begin{abstract}
This study uses stakeholder analysis analysis that has not been applied in several previous studies. This research is also important, because banks need to get information about the determination of the impact on market share, as long as market share is used as a key to company growth and a reflection for stakeholders in assessing their financial performance. Based on the background discussed earlier, the researchers conducted this study aimed at understanding how financial performance affects the Islamic Syariah Bank's marketshare. This research method uses panel data regression, with the model used in this study is a fixed effect using the Eviews 10. application. The results of this study indicate that simultaneously all exogenous variables (ROA, NPF, BOPO and FDR) significantly influence endogenous variables ( market share). Seen in R2 it is intended that variations in the endogenous model in the market share model can be explained by the exogenous variables of ROA, NPF, BOPO, and FDR by $62 \%$ and $38 \%$ are influenced by other variables outside the exogenous variables used in this study. The partial results of ROA, NPF, BOPO, and FDR variables have a significant negative effect on market share.
\end{abstract}

Keywords: ROA, NPF, BOPO, FDR, market share.

\section{PENDAHULUAN}

Perbankan Syariah di Indonesia adalah bagian integral dari pengembangan sistem nasional perbankan (Andriansyah, 2009). Perbankan Syariah adalah salah satu pilihan alternatif bagi nasabah untuk berinvestasi dan peminjaman uang dengan sistemasi halal. Operasional perbankan Indonesia menggunakan sistem ganda, yaitu sistem bank konvensional dan bank Syariah. Pada Juli 2019 Otoritas Jasa Keuangan (OJK) menyatakan bahwa terdapat 12 Bank Umum Syariah (BUS), 22 Unit Usaha Bank Syariah (UUS), dan 165 Bank Pembiayaan Rakyat Syariah ( BPRS), yang terdaftar di Bank Indonesia. Secara historis, Bank Syariah di Indonesia bertumbuh cukup pesat. Otoritas Jasa Keuangan menyatakan bahwa pada bulan Juli 2019, total asset seluruh Bank Indonesia adalah 8.258 Triliun Rupiah bertumbuh sebesar 9,21\%. Hal ini menunjukkan adanya pertumbuhan trend positif, meskipun tidak diikuti oleh peningkatan pangsa pasar. Dapat dilihat pada tabel 1 di bawah ini yang menunjukkan perbandingan total asset seluruh pangsa pasar Bank di Indonesia setiap tahunnya. 
Tabel 1. Total Aset Bank Islam di Indonesia

\begin{tabular}{|l|l|l|l|l|l|}
\hline & $\mathbf{2 0 1 5}$ & $\mathbf{2 0 1 6}$ & $\mathbf{2 0 1 7}$ & $\mathbf{2 0 1 8}$ & $\mathbf{2 0 1 9}$ \\
\hline Asset (Billion) & 6.129 .146 & 6.729 .799 & 7.387 .634 & 8.068 .346 & 8.258 .904 \\
\hline
\end{tabular}

Source: OJK Statistik Bank Islam 2015 - 2019

Pangsa pasar adalah presentase perbandingan antara total asset bank Syariah di Indonesia dan Bank Indonesia (Purboastuti, 2015). Kemampuan dalam mengembangkan pangsa pasar menunjukkan atas keberhasilan kinerja perbankan. Financial performance suatu perusahaan mempunyai hubungan dengan pangsa pasar yang mana sebagai alat ukur para investor dilihat dari segi financial performance perusahaan khususnya pada penelitian ini adalah financial performance Bank Syariah. Kemapuan Bank Syariah untuk menujukkan kabar baik dapat dilihat dari analisis rasio di Laporan Keuangannya. Pada tabel.2. menunjukkan pertumbuhan rasio keuangan di Bank Syariah Indonesia.

Tabel 2. Data Rasio Keuangan Bank Islam di Indonesia

\begin{tabular}{|l|l|l|l|l|}
\hline Year & ROA & NPF & BOPO & FDR \\
2016 & $0.63 \%$ & $2.17 \%$ & $96.22 \%$ & $85.99 \%$ \\
2017 & $0.63 \%$ & $2.57 \%$ & $94.91 \%$ & $79.61 \%$ \\
2018 & $1.28 \%$ & $1.95 \%$ & $89.18 \%$ & $78.53 \%$ \\
2019 & $1.62 \%$ & $2.00 \%$ & $85.58 \%$ & $79.90 \%$
\end{tabular}

Sumber: OJK, Statistik Bank Islam 2016 - 2019

Tabel 2. menunjukkan bahwa semua rasio keuangan berfluktuasi di setiap tahunnya. Oleh karena itu, hal ini menunjukkan ketidakstabilan dalam financial performance. Financial performance adalah salah satu bentuk pengukuran kinerja bank. Kinerja perusahaan diukur dari nilai total yang diciptakan dari aktivitas perusahaan, yang meliputi jumlah utilitas dari masingmasing stakeholder perusahaan (Freeman, 1984). Financial performance sangat penting bagi beberapa stakeholder, tetapi hal itu bukan satu-satunya item pencipataan nilai penting (Harrison dan Wicks, 2013). Beberapa perusahaan menggunakan Financial performance yang difokuskan pada return, untuk melihat keuntungan yaitu diantaranya return on ivestment (ROI), economic rents, atau return pemegang saham (Barney, 2011). Menurut logika tujuan utama perusahaan untuk pelanggannya adalah untuk menciptakan barang dan jasa yang dianggap memberikan rasio yang sangat positif baik utilitas yang diterima maupun nilai yang ditawarkan (Barney, 2011). Purboastuti (2015) menemukan bahwa terdapat beberapa faktor internal sebagai penentu pengaruhnya market share yaitu, rasio profitabilitas (ROA), tingkat default (NPF), dan rasio likuiditas (FDR). Dalam penemuan Rahman (2016) juga terdapat bahwasannya tingkat default, Rasio efesiensi operasional, dan persyaratan modal minimum berpengaruh pada market share bank Syariah. Market share merupakan sebagai penentu kinerja bank Syariah, dan juga sangat berpengaruh pada profitabilitas Bank Syariah (Mirzae, 2010). Pada umumnya, peningkatan market share bank Syariah dapat meningkatan kontribusi pada ekonomi Indonesia.

Peningkatan market share Bank sangat berhubungan dengan marketing. Area marketing mncerminkan bagaiman pelanggan menentukan jumlah nilai mereka untuk sesuatu yang mereka inginkan (Harisson dan Wicks, 2013). Sehingga, bagaimana market share perusahaan meningkat dipengaruhi oleh keberhasilan dalam memberikan nilai kepada para stakeholder. Barney (2011) menyatakan dalam konsep teori stakeholder, financial performance sangat penting karena itu posisi yang utama dalam perusahaan. Financial performance adalah hal utama yang dilihat oleh stakeholder untuk menilai kesuksesan perusahaan (Barney, 2011). Sehingga perusahaan yang berhasil menyediakan kedua rasio tersebut akan menciptakan pemikiran yang baik tentang perspektif para pemangku kepentingan.

Pada penelitian ini kita menggunakan analisis teori stakeholder yang belum diterapkan dalam beberapa penelitian sebelumnya. Penelitian ini juga penting, karena bank perlu mendapatkan informasi tentang determinasi dampak pada market share, selama market share dijadikan sebagai kunci pertumbuhan perusahaan dan cerminan untuk para stakeholder dalam menilai financial 
performancenya. Berdasarkan latar belakang yang telah dibahas sebelumnya, peneliti melakukan penelitian ini bertujuan untuk memahami bagaimana financial performance mempengaruhi marketshare Bank Syariah Indonesia.

\section{Teori Stakeholder}

\section{TINJAUAN PUSTAKA}

Stakeholder adalah orang atau kelompok yang memiliki hubungan lebih dekat dan hampir tidak berdampak pada kegiatan perusahaan (Phillip, dkk. 2003). Terdapat banyak interprestasi yang berbeda tentang teori gagasan pengembangan dasar stakeholder (Scherer dan Petzer, 2011). Asumsi dasar dari beberapa studi dari perspektif stakeholder dalam pengukuran ekonomi dapat ditunjukan dengan nilai kreasi, yang mana hal itu didapatkan dari laporan untuk stakeholder (Harrison dan Wicks, 2013). Freeman dkk. (2007) menyatakan bahwa stakeholder terfokus pada nilai dan peningkatan operasional perusahaan. Freeman (1984) sebelumnya juga menyatakan bahwa stakeholder bergantung pada perusahaan dalam memuaskan kepentingan mereka sendiri. Fokus utama dalam beberapa literasi teori stakeholder juga banyak yang membahas bahwasannya stakeholder mengelola dengan baik dengan hal untuk kepentingan mereka sendiri. Harrison dan Wicks (2013) berpendapat bahwa ada empat faktor yang didefinisikan dalam hal utilitas yang diarasakan oleh para stakeholder perusahaan: 1) utilitas stakeholder yang terkait dengan barang dan jasa aktual; 2) utilitas stakeholder terkait dengan keadian berorganisasi; 3) utilitas stakeholder terkait dengan persepsi opportunity cost. Berdasarkan argument tersebut, peneliti dapat menyimpulkan bahwa utilitas yang diharapkan stakeholder dipengaruhi dengan bagaimana perusahaan bertindak untuk memberikan mereka kepuasan. Financial performance adalah indicator ekonomi yang mencerminkan bentuk pertanggung jawaban perusahaan kepada para stakeholder perusahaan.

\section{Hipotesis Penelitian}

Beberapa penelitian sebelumnya telah juga telah ada yang mengunakan perbankan Syariah di Indonesia. Airout (2017) mengevaluasi financial performance dari dua Bank Islam yaitu Jordan Islamic Bank dan Arab Islamic International Bank. Dengan menggunakan metode perbandingan dalam mengajukan indicator keuntunan, namun mereka tidak menemukan perbedaan yang signifikan pada kedua bank tersebut. Setyawati (2017) menganalisis faktor internal dan eksternal yang berdampak pada kinerja perbankan Islam di Indonesia. Mereka juga mempelajari pengaruh krisis global terhadap financial performance di Bank Syariah Indonesia. Mereka menghasilkan bahwa kinerja bank Syariah secara signifikan dipengaruhi oleh inflasi dan NPF. Ahmed (2017) menyatakan bahwasanya terdapat dampak positif antara profitabilitas yang diukur oleh EPS, ROE, dan CG. Namun, ditemukan juga pada penelitian tersebut bahwa CGI dan ROA tidak berpengaruh signifikan, Masood dkk. (2016) menganalisis bank Syariah yang beroperasi di Pakistan pada tahun 2015 yang mana performance financial masih menggunakan model peringkat CAMELS, dan menunjukkan bahwa bank Syariah memberikan hasil yang memuaskan. Meskipun masih membutuhkan untuk mengembangkan pasar keuangan untuk beroperasi secara treasury yang sehat. Samhan dan Al- Khatib (2015) meneliti faktor-faktor penentu financial performance pada Jordan Islamic Bank di tahun 2000 - 2012. Financial performance diproksi dengan Return on Asset (ROA), Return on Equity (ROE), dan Return on Unrestricted Investment Accounts (ROUIA). Mereka menemukan adanya hubungan positif signifikan antara ROUIA dengan GDP. Lebih lanjutnya, mereka menyatakan adanya hubungan positif signifikan antara ROUIA dengan tingkat inflasi, total pendapatan terhadap total asset, rasio ekuitas, dan size bank. Namun, terdapat sebaliknya ada yang berpengaruh negative signifikan antara ROUIA dengan tingkat penggangguran, dan juga terjadi antara ROUIA dengan rasio hutang, dan rasio likuiditas.

Obeidat, dkk. (2013) menemukan bahwa hal yang penting dalam faktor internal adalah profitabilitas, seperti total setoran, biaya deposito, total pengeluaran, pembiayaan mudharabah dan investasi berbasis deposito. Sebaliknya, faktor eksternal yang utama adalah jumlah uang beredar dan pangsa pasar. Pangsa pasar adalah salah satu faktor eksternal yang mempengaruhi profitabilitas. Saputra (2014) menemukan bahwa ROA, CAR, dan FDR berpengaruh signifikan terhadap efek pangsa pasar, meskipun pada NPF dan REO tidak berpengaruh signifikan. 
Purboastuti, dkk. (2015) menemukan bahwa ROA, NPF, dan FDR berpengaruh terhadap pangsa pasar, diikuti dengan Dana Pihak Ketiga (DPK) dan ROA ditemukan adanya berpengaruh positif signifikan terhadap market share. Zulfiah dan Susilowibowo (2014) menemukan adanya NPL dan CAR berpengaruh positif signifikan terhadap market share. Namun, sebaliknya ROA, BI rate, dan BOPO mempunyai pengaruh negative signifikan terhadap marketshare. Financial performance adalah sebagai cerminan kondisi keuangan suatu perusahaan dalam satu periode. Pada bank kondisi ini terdiri dari pendanaan, dan pembiayaan yang dinilai dari kecukupan modal, likuiditas, dan profitabilitas (Jumingan, 2016). Kasmir (2012) menyatakan bahwa analisis rasio adalah aktivitas perbandingan dalam penilaian keuangan perusahaan. Berdasarkan literasi di atas, definisi variabel yang akan digunakan adalah berikut:

\section{METODOLOGI PENELITIAN}

Penelitian ini menggunakan data panel dari Bank Umum Syariah di Indonesia khususnya pada Bank Umum Syariah Devisa. Bank Umum Syariah Devisa saat ini terdapat 6 bank yaitu, Bank Mega Syariah, Bank Muammalat, Bank BNI Syariah, Bank BRI Syariah, Bank Syariah Mandiri, dan Bank Panin Dubai Syariah. Penelitian ini menggunakan laporan keuangan triwulan dari Q12017 - Q22019, sehingga observasi pada data ini berjumlah 84. Penelitian ini menggunakan metode kuantitatif, yaitu akan menguji variabel endogen dan eksogen dengan regresi data panel. Penelitian ini akan menguji korelasi antara variabel eksogen dan variabel endogen, yiatu variabel eksogen adalah ROA, NPF, BOPO dan FDR, sedangkan variabel endogen adalah market share. Model yang digunakan pada penelitian ini adalah fixed effect dengan menggunakan aplikasi Eviews 10. Model fixed effect adalah model dengan intercept berbeda- beda untuk setiap subjek (cross section), tetapi slope setiap subjek tidak berubah seiring waktu (Gujarati, 2012). Model ini mengasumsikan bahwa intercept adalah berbeda setiap subjek sedangkan slope tetap sama antar subjek. Dalam membedakan satu subjek dengan subjek lainnya digunakan variabel dummy (Kuncoro, 2012). Model ini sering disebut dengan model Least Square Dummy Variables (LSDV). Dimana variabel dummy d1t untuk subjek pertama dan 0 jika bukan, $d 2 t$ untuk subjek kedua dan 0 jika bukan, dan seterusnya. Jika dalam sebuah penelitian menggunakan 10 cross section, maka jumlah variabel dummy yang digunakan sebanyak 9 variabel untuk menghindari perangkap variabel dummy, yaitu kondisi dimana terjadi kolinearitas sempurna (Gujarati, 2012). Intercept b0 adalah nilai intercept subjek kesatu dan koefisien b6, b7, b8 menandakan besar perbedaan antara intercept subjek lain terhadap subjek kesatu. Dari pembahasan di atas, maka kerangaka konseptual penelitian ini adalah:

\section{HASIL DAN PEMBAHASAN}

Hasil dari statitistik deskriptif menyatakan bahwa ROA Bank Panin Dubai Syariah pada quartal ke 42017 adalah yang terendah hanya -10,77\% (mengalami kerugian). Sebaliknya ROA yang tertinggi adalah Bank BNI Syariah pada quartal 2 tahun 2019 sebesar 1,97\%. Sementara itu, standar deviasi untuk ROA adalah 1,48\%, yang mana lebih tinggi dari nilai rata- rata yang sebesar 0,75\%. Dalam NPF, score terendah diperoleh oleh Bank Muammalat Indonesia Q2 tahun 2018 dengan jumlah NPF sebesar 0,88\%, dan NPF yang tertinggi adalah Bank BRI Syariah pada Q4 tahun 2018 dengan jumlah NPF sebesar 4,97\%, NPF pada penelitian ini dengan stadar deviasi sebesar 1,03\% lebih rendah dari nilai rata-rata sebesar 2,83\%, hal ini menunjukkan NPF pada bank Syariah di Indonesia masih dalam tahap aman. Selanjutnya, BOPO yang memiliki score terendah adalah Bank BNI Syariah pada Q2 tahun 2019 sebesar 79,85\%, sedangkan score tertinggi ditujukan pada Bank Panin Dubai Syariah sebesar 217,4 \%. Dengan standar deviasi BOPO sebesar 14,43\%, lebih rendah dari rata-rata BOPO yang sebesar 93,86\%. Pada FDR yang memiliki score terendah adalah Bank Muammalat Indonesia pada Q2 tahun 2019 yang sebesar 68,05\%, sedangkan nilai tertinggi ditujukan pada Bank Mega Syariah pada Q1 tahun 2019 yang sebesar 99,23\%, dengan standar deviasi FDR sebesar 8,24 yang lebih rendah dengan besaran rata- ratanya yaitu 85,31\%. Sebelum mengetahui hasil dari pengolahan data dari penelitian ini, data yang akan dianalisis diuji menggunakan eviews 10, dapat dilihat pada tabel 3 . 
Tabel 3. Uji Chow dan Uji Hausman

\begin{tabular}{|l|l|l|}
\hline Test Type & Probabilitas & Hasil Hipotesis \\
Uji Chow & 0.0014 & Tolak H, maka FEM \\
Uji Hausman & 0.0004 & Tolak H, maka FEM
\end{tabular}

Nilai probabilitas yang diperoleh pada Uji Chow di table 3. sebesar 0.0014, hasil tersebut kurang dari taraf nyata yang digunakan dalam peneliltian ini yaitu sebesar 5\% maka cukup bukti untuk menolak HO. Berdasarkan hasil uji tersebut menunjukkan bahwa model fixed effect diterima dibanding PLS. Selanjutnya, hasil uji Hausman menunjukkan nilai probabilitas 0.0004, nilai probabilitas tersebut lebih kecil dari taraf 5 persen sehingga cukup bukti untuk menolak hipotesis HO. Keputusan pada Uji Chow dan Uji Hausman menunjukkan bahwa model FEM merupakan pendekatan terbaik.

Tabel 4. Hasil Analisis Regresi Linier Berganda

Variable Coefficient Std. Error t-Statistic Prob.

\begin{tabular}{lllll}
\hline C & 56.71028 & 17.16826 & 3.303205 & 0.0018 \\
ROA & -3.642703 & 1.687819 & -2.158231 & 0.0356 \\
NPF & -1.197748 & 0.377059 & -3.176555 & 0.0025 \\
BOPO & -0.324963 & 0.154487 & -2.103495 & 0.0404 \\
FDR & -0.182605 & 0.068298 & -2.673644 & 0.0101
\end{tabular}

\begin{tabular}{llll}
\hline R-squared & 0.617366 & Mean dependent var & 5.162721 \\
Adjusted R-squared & 0.557345 & S.D. dependent var & 3.863902 \\
S.E. of regression & 2.570745 & Akaike info criterion & 4.863750 \\
Sum squared resid & 337.0452 & Schwarz criterion & 5.177901 \\
Log likelihood & -136.9125 & Hannan-Quinn criter. & 4.986632 \\
F-statistic & 10.28582 & Durbin-Watson stat & 1.068578 \\
Prob(F-statistic) & 0.000000 &
\end{tabular}

Hasil penelitian menunjukkan bahwasannya $\mathrm{R}^{2}$ sebesar 0.617366 , hal ini ditujukan bahwa variasi model endogen pada model market share dapat dijelaskan oleh variabel- variabel eksogen ROA, NPF, BOPO, dan FDR sebesar 62\% dan 38\% dipengaruhi oleh variabel lainnya diluar variabel eksogen yang digunakan penelitian ini yang merupakan hasil dari Regresi Data Panel Least Square, menyatakan bahwa variabel ROA berpengaruh negative signifikan dengan market share. Dilihat dari nilai probabilitasnya adalah sebesar 0,03 dimana lebih kecil dari 0,05, maka hal ini H1 diterima, dan dinyatakan bahwa ROA berpengaruh negative signifikan terhadap market share. Dalam teori stakeholder hasil temuan ini tidak sejalan, karena ROA mencerminakan kemampuan perusahaan dalam menciptakan nilai, dengan itu para stakeholder akan dengan mudah puas terhadap kinerja perusahaan atas kepentingan mereka (Sachs dan Riihli, 2011). Dengan ini, ROA pada bank syariah Indonesia dapat disimpulkan bahwa profitabilitas bank syariah pada periode penelitian ini tidak sebagai acuan para stakeholder, sehingga dapat menurunkan marketshare bank syariah pada periode penelitian ini.

Variabel NPF menunjukkan bahwa probabiltasnya sebesar $0.0025<$ dari 0.05 , dengan ini disimpulkan bahwa $\mathrm{H} 2$ diterima NPF berpengaruh negatif signifikan terhadap marketshare. Setiap NPF meningkat 1 persen maka akan menurunkan marketshare sebesar 1,19\%. Hal ini menyatakan bahwa semakin tinggin pinjaman macet bank, maka semakin rendah kepercayaan publik terhadap manajemen mereka. Dengan kata lain, kredit macet meningkatkan risiko nasabah untuk menabung, sehingga dana pihak ketiga akan berkurang karena ketidakpercayaan publik, penemuan ini sejalan dengan Zulfiah dan Susilowibowo (2014) dan Purboastuti, dkk. (2015). Kepercayaan sangatlah 
penting sebagai timbal balik dan petukuran umum sebagai pemupuk keadilan dalam hubungan antar pihak (Mayer, dkk. 1995) sebagai stakeholder perusahaan. Variabel BOPO menunjukkan bahwa probabilitasnya sebesar $0.04<0.05$, dengan ini dinyatakan bahwa H3 diterima, BOPO berpengaruh negatif signifikan terhadap marketshare. Setiap BOPO meningkat 1 persen maka akan menurunkan marketshare sebesar $0.32 \%$. Semakin sedikit BOPO pada bank syariah, semakin efesien dalam sistem manajemen operasional. Oleh karena itu, BOPO harus agar lebih efesien dan dapat meningkatakan kepercayaan publik, hal ini didukung oleh temuan Zulfiah dan Susilowibowo (2014). Preferensi stakeholder berasal dari persepsi tentang bagaiman transaksi, hubungan dan interaksi dengan perusahaan (Harrison dan Wicks, 2013). Sehingga, saat bank menghasilkan efesiensi dalam kegiatan operasional, preferensi mereka terhadap bank akan tinggi, karena bank secara khusus memperlakukan dengan baik dan mengelola untuk kepentingan mereka (Freeman, dkk. 2007). Variabel FDR menunjukkan bahwa probabilitasnya sebesar $0.01<0.05$, dengan ini dinyatakan bahwa H4 diterima, FDR berpengaruh negatif signifikan terhadap marketshare. Maka, setiap FDR naik 1 persen akan menurunkan marketshare sebesar 0,18\%. Dana yang dihimpun masyarakat disalurkan kepada pihak yang membutuhkan dana oleh bank syariah.

Saputra (2014) menyatakan bahwa jika rasio ini meningkat dalam batas tertentu maka akan semakin banyak dana yang disalurkan dalam bentuk pembiayaan, sehingga akan meningkatkan market share bank syariah, dengan asumsi bank menyalurkan dananya untuk pembiyaan yang efektif. Namun, penelitian ini tidak sejalan dengan itu dan penelitian yang dilakukan Purboastuti, dkk (2015) yang menyatakan bahwa FDR akan meningkatkan market share bank syariah. Pada penelitian ini dapat disimpulkan bahwasannya rasio dana yang dihimpun untuk disalurkan bank syariah dalam pembiayaan belum maksimal, sehingga dapat mengurangi nilai market share pada para stakeholder bank syariah.

\section{KESIMPULAN}

Hasil penelitian menujukkan bahwa secara simultan seluruh variabel eksogen (ROA, NPF, BOPO dan FDR) berpengaruh signifikan terhadap variabel endogen (market share). Secara parsial variabel ROA, NPF, BOPO, dan FDR berpengaruh negatif signifikan terhadap market share. ROA berpengaruh negative signifikan terhadap market share, dengan ini dinyatakan bahwa ROA pada bank syariah Indonesia dapat disimpulkan bahwa profitabilitas bank syariah pada periode penelitian ini tidak sebagai acuan para stakeholder, sehingga dapat menurunkan marketshare bank syariah pada periode penelitian ini. NPF berpengaruh negatif terhadap market share, hal ini menyatakan bahwa semakin tinggi pinjaman macet bank, maka semakin rendah kepercayaan publik terhadap manajemen mereka . Dengan kata lain, kredit macet meningkatkan risiko nasabah untuk menabung, sehingga dana pihak ketiga akan berkurang karena ketidakpercayaan publik. BOPO berpengaruh negatif signifikan terhadap market share, hal ini menyatakan bahwa semakin sedikit BOPO pada bank syariah, semakin efesien dalam sistem manajemen operasional (Freeman, dkk. 2007). FDR berpengaruh negatif signifikan terhadapa market share, hal ini menyatakan bahwasannya rasio dana yang dihimpun untuk disalurkan bank syariah dalam pembiayaan belum maksial, sehingga dapat mengurangi nilai market share pada para stakeholder bank syariah. Penelitian masih terbatas, karena sampel yang digunakan hanya bank Umum Syariah Devisa tidak keseluruhan bank syariah di Indonesia. Financial Performance yang digunakan masih belum semua digunakan dalam variabel eksogen seperti CAR, dana pihak ketiga, dan lainnya. Penelitian selanjutnya diharapkan dapat menambahkan variabel financial performance yang lainnya dan menggunakan teori yang lain selain teori stakeholder.

\section{DAFTAR PUSTAKA}

Ahmed, Ibrahim Elsiddig. The impact of corporate governance on Islamic Banking Performance: The Case of UAE Islamic Banksll, Journal of Banking \& Finance, (09): 1-10, 2017.

Airout, Rana M. and Airout, Rula M. Evaluation of Financial Performance of Islamic Banks in Jordan (2001- 2010), A Comparative Studyll, International Journal of Economics and Finance; 9 (9): 166-174, 2017. 
Andriansyah, Y, Indonesia Islamic Bank Financial Performancell, Jurnal Ekonomi Islam, 3 (2), 81 196, 2009.

Bank Indonesia, Bank Indonesia and Its Contribution on the National Developmentl Cetak Biru Pengembangan Perbankan Syariah Indonesia (Blue Print of The Development of Indonesia Islamic bank), 2007, Retrieved on September 23, 2016 www.perpustakaan.kemenkeu.go.id

Barney, J, Gaining and sustaining competitive advantage (4th ed.). Upper Saddle River, NJ:Pearson Education, Inc, 2011.

Ekeh, P. P., Social exchange theoryll, Cambridge, MA: Harvard University Press, 19

Freeman, R. E., Strategic management: A stakeholder approachll, Boston: Pitman, 2017

Harrison, Jeffrey S, and Wicks, Andrew C., Stakeholder Theory, Value, and Firm Performancell, Business Ethics Quarterly, 23(1): 97-124, 2013

Jumingan, Financial Report Analyis", Jakarta: PT. Bumi Aksara, 2006

Kasmir. Financial Report Analyis\|, Jakarta: PT. Rajagrafindo Persada, 2012

Masood, Omar; Ghauri, Shahid Mohammad Khan; and Aktan, Bora, Predicting Islamic banks performance through CAMELS rating modell, Banks and Bank Systems, 11(3): 37-43, 2016

Mayer, R. C, Davis, J. H., \& Schoorman, F. D, An integrative model of organizational trustl, Academy of Management Review, 20, 709-34.

Mirzaei, Ali; Liu, Guy; and Moore, Tomoe. (2011). Does market share matter on bank's profitability and stability?: Emerging versus advances economies. Bruney University, 1995

Obeidat, Bader Yousef; El-Rimawi, Salaheddin Y.; Masa'deh, Ra'ed (Moh'd Taisir); Maqableh, Mahmoud Mohammad; Al-Jarrah, Idries Mohammed, -Evaluating the Profitability of the Islamic Banks in Jordanll, European Journal of Economics, Finance and Administrative Sciences. 56: 27-36, 2013

Otoritas Jasa Keuangan, Islamic Banking Statistics, January 2013-Juli 2016\|, Retrieved on September 23, 2016, http://www.ojk.go.id, 2016

Phillips, R. A., Freeman, R. E., \& Wicks, A. C, What stakeholder theory is notl, Business Ethics Quarterly, 13: 479-502, 2003

Purboastuti, N., Anwar, N., \& Suryahani, I, Pengaruh Indikator Utama Perbankan Terhadap Pangsa Pasar Perbankan Syariah , Journal of Economics and Policy, 8(1): 13-22, 2015

Rahman, A., Analysis of Factors That Influence The Islamic Bank's Market Sharell, Analytica Islamica, 5(2): 291-314, 2016

Sachs, S., \& Riihli, E, Stakeholders matter: A new paradigm for strategy in society, Cambridge:Cambridge University Press, 2011

J. Williams, Narrow-Band Analyzer, PhD dissertation, Dept. of Electrical Eng., Harvard Univ., Cambridge, Mass., 1993. (Thesis or dissertation)

E.E. Reber, R.L. Michell, and C.J. Carter, Oxygen Absorption in the Earth's Atmosphere, Technical Report TR-0200 (420-46)-3, Aerospace Corp., Los Angeles, Calif., Nov. 1988. (Technical report with report number)

L. Hubert and P. Arabie, Comparing Partitions, J. Classification, vol. 2, no. 4, pp. 193-218, Apr. 1985. (Journal or magazine citation)

R.J. Vidmar, On the Use of Atmospheric Plasmas as Electromagnetic Reflectors, IEEE Trans.

Plasma Science, vol. 21, no. 3, pp. 876-880, available at http://www.halcyon.com/pub/journals/21ps03-vidmar, Aug. 1992. (URL for Transaction, journal, or magzine)

J.M.P. Martinez, R.B. Llavori, M.J.A. Cabo, and T.B. Pedersen, "Integrating Data Warehouses with Web Data: A Survey," IEEE Trans. Knowledge and Data Eng., preprint, 21 Dec. 2007, doi:10.1109/TKDE.2007.190746.(PrePrint). 